\title{
Transferability and characterization of microsatellite markers in five Bromeliaceae species belonging to the subfamilies Pitcairnoideae and Bromelioideae
}

\author{
Fabio Demolinari de Miranda ${ }^{1}$, Andreia Barcelos Passos Lima Gontijo ${ }^{2,5}$, Fabiano Costa Santiliano ${ }^{1}$, \\ Fernanda Campanharo Favoreto ${ }^{3} \&$ Taís Cristina Bastos Soares ${ }^{4}$

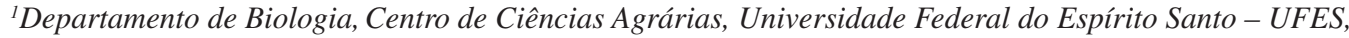 \\ Alto Universitário, s/n, CEP 29500-000, Alegre, ES, Brazil. http://www.cca.ufes.br \\ ${ }^{2}$ Departamento de Ciências Agrárias e Biológicas, Centro Universitário Norte do Espírito Santo, \\ Universidade Federal do Espírito Santo - UFES, Rod. BR 101 Norte, Km 60, \\ CEP 29932-540, São Mateus, ES, Brazil. http://www.ceunes.ufes.br \\ ${ }^{3}$ Instituto de Ciências Biológicas, Programa de Pós-graduação em Ecologia, \\ Universidade Federal de Juiz de Fora - UFJF, Campus Universitário, \\ CEP 36036-900, Juiz de Fora, MG, Brazil. http://www.ufjf.br/ecologia \\ ${ }^{4}$ Departamento de Farmácia e Nutrição, Centro de Ciências Agrárias, \\ Universidade Federal do Espírito Santo - UFES, Alto Universitário, s/n, \\ CEP 29500-000, Alegre, ES, Brazil. http://www.cca.ufes.br \\ ${ }^{5}$ Corresponding author: Andreia Barcelos Passos Lima Gontijo, e-mail: albarcelos@ hotmail.com
}

MIRANDA, F.D., GONTIJO, A.B.P.L., SANTILIANO, F.C., FAVORETO, F.C. \& SOARES, T.C.B. Transferability and Characterization of Microsatellite Markers in five Bromeliaceae species belonging to the subfamilies Pitcairnioideae and Bromelioideae. Biota Neotrop. 12(3): http://www.biotaneotropica.org.br/ v12n3/en/abstract?short-communication+bn02812032012

\begin{abstract}
Microsatellite markers previously developed for Pitcairnia albiflos Herb. and Pitcairnia geysksii L.B.Sm. were used in cross-amplification tests of five other Bromeliaceae species. Ten (76.9\%) out of the 13 evaluated pair of primers had positive results for some of the species tested. The number of polymorphic alleles ranged between two and four in most species. $\mathrm{H}_{\mathrm{o}}$ values ranged between zero, in Pitcairnia flammea Lindl. (PaA05), Aechmea ramosa Mart ex Schult \& Schult and Billbergia horrida Regel (PaC05), and one in Billbergia euphemiae E. Morren (PaA05, PaA10, PaC05 and PaD07). This study showed that microsatellite markers developed for P. albiflos and P. geysksii effectively amplified the DNA samples of Pitcairnia flammea, Aechmea nudicaulis(L.) Griseb., Aechmea ramosa, Billbergia horrida and Billbergia euphemiae, validating the transferability of these markers to species of the Pitcairnioideae and Bromelioideae subfamilies.
\end{abstract}

Keywords: cross-amplification, SSR, genetic diversity, bromeliads, conservation.

MiRANDA, F.D., GONTIJO, A.B.P.L., SANTILIANO, F.C., FAVORETO, F.C. \& SOARES, T.C.B. Transferibilidade e caracterização de marcadores microssatélites em cinco espécies de Bromeliaceae pertencentes às subfamílias Pitcairnioideae e Bromelioideae. Biota Neotrop. 12(3): http://www.biotaneotropica. org.br/v12n3/pt/abstract?short-communication+bn02812032012

Resumo: Marcadores microssatélites originalmente desenvolvidos para Pitcairnia albiflos Herb. e Pitcairnia geysksii L.B.Sm. foram testados para amplificação heteróloga do genoma de cinco outras espécies de Bromeliacea. Dos treze pares de primers avaliados, dez $(76,9 \%)$ geraram resultados positivos para algumas das espécies em estudo. O número de alelos polimórficos por loco variou entre dois e quatro para a maioria das espécies. Os valores de $\mathrm{H}_{\mathrm{O}}$ variaram entre zero em Pitcairnia flammea Lindl. (PaA05), Aechmea ramosa Mart ex Schult \& Schult e Billbergia horrida Regel (PaC05) e um para Billbergia euphemiae E. Morren (PaA05, PaA10, PaC05 e PaD07). Este estudo demonstrou que marcadores microssatélites desenvolvidos para P. albiflos e P. geysksii mostraram-se eficientes para amplificação heteróloga de amostras de DNA de Pitcairnia flammea, Aechmea nudicaulis(L.)Griseb., Aechmea ramosa, Billbergia horrida e Billbergia euphemiae, validando a transferibilidade destes marcadores para espécies das subfamílias Pitcairnioideae e Bromelioideae.

Palavras-chave: amplificação heteróloga, SSR, diversidade genética, bromélias, conservação. 


\section{Introduction}

The family Bromeliaceae plays an important role in the conservation of neotropical plant diversity. These epiphytic plants of the Atlantic Forest are among the most visited by birds, also serving as shelter and food for other species (Pizo 1994, Siqueira Filho \& Leme 2000). The family Bromeliaceae is organized into three subfamilies: Pitcairnioideae, Tillandsioideae and Bromelioideae (Cronquist 1988), including 3172 species grouped into 58 genera (Luther 2008).

Many members of this family have economic value, e.g. the pineapple plant (Ananas comosus (L.) Murril), the 'caroa' (Neoglaziovia variegata (Arruda) Mez), which produces fibers and the ornamental plants, especially those of the Aechmea, Billbergia, Canistrum and Cryptanthus genera (Benzig 2000).

Despite their ecological and economic importance, little is known about genetic structure and diversity in natural populations of Bromeliads. According to Cavallari et al. (2006), preservation of the genetic diversity has become the main focus of most conservation programs and knowing the distribution of this diversity within and between natural populations is the first step. Understanding genetic variation within the populations of a given species is an essential prerequisite for conservation action (Barbará et al. 2007), which is essential for the establishment of sustainable forms of economic exploitation.

Therefore, the use of molecular genetic markers to assess genetic diversity of populations plant species occurring in Atlantic Forest has been reported in several studies (Chen et al. 2002, Boneth et al. 2003, Cavallari et al. 2006). Because of their greater convenience, the molecular markers most commonly used in analysis of genetic diversity in plants are polymerase chain reaction-based assays (PCR), particularly microsatellite or Simple Sequence Repeats (SSR) (Litt \& Luty 1989), for they are a group of markers highly informative due to their multiallelic and codominant nature, reproducibility, heritability, relative abundance and extensive genome coverage (Powell et al. 1996, Yamamoto et al. 2002).

However, the main limitation on the use of these markers for analysis of genetic diversity in different species is the high cost for developing specific primers. An alternative approach would be the cross amplification of primers. SSR markers can be transferred between related species and genera, which considerably reduces their costs (Ferreira \& Grattaplaglia 1998). SSR transferability has been reported to many families of plants, including Fabaceaea (Peakall et al. 1998, Kölliker et al. 2001) Cucurbitaceae (Katzir et al. 1996), Poaceae (Saghai Maroof et al. 1994, Röder et al. 1995, Thiel et al. 2003), Solanaceae (Provan et al. 1996, Smulders et al. 1997, Nagy et al. 2007, Moon et al. 2008); Euphorbiaceae (Yu et al. 2011) and Bromeliaceae (Sarthou et al. 2003, Barbará et al. 2007, Paggi et al. 2008). Thus, in this paper eight microsatellite markers previously developed for Pitcairnia albiflos and five markers developed for Pitcairnia geysksii were used in cross-amplification tests of five other neotropical Bromeliaceae species (Pitcairnia flammea, Aechmea nudicaulis, Aechmea ramosa, Billbergia horrida and Billbergia euphemiae).

\section{Materials and Methods}

Five markers of microsatellite loci previously developed for Pitcairnia geysksii (Sarthou et al. 2003) and eight to Pitcairnia albiflos (Paggi et al. 2008) (Table 1) were used in cross- amplification tests of five other Bromeliaceae species belonging to the Pitcairnioideae (Pitcairnia flammea) and Bromelioideae (Aechmea nudicaulis, Aechmea ramosa, Billbergia horrida and Billbergia euphemiae) subfamilies. A total of 12 P. flammea individuals $\left(20^{\circ} 40^{\prime} 52.39^{\prime \prime} \mathrm{S}\right.$ and $\left.41^{\circ} 20^{\prime} 43.38^{\prime \prime} \mathrm{W}\right)$, eight $A$. nudicaulis (20 $40^{\circ} 30.83$ ' $\mathrm{S}$ and $41^{\circ} 20^{\prime}$ $\left.57.01^{\prime \prime} \mathrm{W}\right), 12$ of $A$. ramosa $\left(20^{\circ} 40^{\prime} 30.83^{\prime \prime} \mathrm{S}\right.$ and $\left.41^{\circ} 20^{\prime} 57.01^{\prime \prime} \mathrm{W}\right)$,
10 of $B$. horrida $\left(20^{\circ} 40^{\prime} 20.1^{\prime \prime} \mathrm{S}\right.$ and $\left.41^{\circ} 22^{\prime} 35.8^{\prime \prime} \mathrm{W}\right)$ and four B. euphemiae $\left(20^{\circ} 40^{\prime} 24,4^{\prime \prime} \mathrm{S}\right.$ and $41^{\circ} 20^{\prime} 55.2^{\prime}$ ' W) were used in the analysis. One voucher for each species (accession $\mathrm{n}^{\circ} 5569, \mathrm{n}^{\circ} 55681$, $\mathrm{n}^{\circ} 55657, \mathrm{n}^{\circ} 55664$ and $\mathrm{n}^{\circ} 55660$ respectively) was deposited in the CESJ Herbarium at Universidade Federal de Juiz de Fora (UFJF).

Leaf samples were collected from individuals of these species in natural populations occurring in fragments of the Atlantic Forests, in Burarama, Cachoeiro de Itapemirim, ES. DNA of plant samples were extracted and purified using the cetyltrimethylammonium bromide (CTAB) extraction method, as described by Doyle \& Doyle (1990).

In order to improve the PCR result, the optimal annealing temperatures of each pair of primers to be tested were determined (between 48 and $56^{\circ} \mathrm{C}$ ). In all cases, microsatellite loci were amplified in a $15 \mu \mathrm{L}$ volume containing $0.4 \mu \mathrm{M}$ of each primer, $1 \mathrm{U}$ Taq DNA polymerase, $0.1 \mathrm{mM}$ of each $\mathrm{dNTP}, 1 \times \mathrm{MgCl}_{2}-$ free reaction buffer (10 mM Tris- $\mathrm{HCl} \mathrm{pH} 8.3$ and $50 \mathrm{mM} \mathrm{KCl}$ ), $2 \mathrm{mM} \mathrm{MgCl}_{2}$ and $30 \mathrm{ng}$ of template DNA.

Amplifications were performed using a Techne TC-412 thermal cycler under the following conditions: 5 minutes denaturation at $94{ }^{\circ} \mathrm{C}$ followed by 30 cycles of 1 minute of initial denaturation at $94{ }^{\circ} \mathrm{C}, 1$ minute of annealing temperature at $54{ }^{\circ} \mathrm{C}$ and 1 minute of extension at $72{ }^{\circ} \mathrm{C}$, and elongation at $72{ }^{\circ} \mathrm{C}$ for 7 minutes.

Amplified fragments were separated by electrophoresis on $2.5 \%$ agarose gel containing $0.02 \mathrm{ug} / \mathrm{mL}$ ethidium bromide, $1 \mathrm{x}$ TBE buffer (0.89 M Tris- $\mathrm{HCl} \mathrm{pH} 8.3,0.89 \mathrm{M}$ boric acid and 0.02 M EDTA), at 110 volts for approximately three hours. Afterwards, the gels were photographed under UV light, using the gel documentation system Biolocus L PIX (Loccus Biotecnologia ${ }^{\circledR}$ ). Gel electrophoresis was used to assess the number and size of amplified fragments, as well as polymorphism detection.

Analyses of genetic variability at the microsatellite loci were done using the genotypes obtained for all five species of bromeliads evaluated in this study. The number of alleles per locus and the observed and expected heterozygosities under Hardy-Weinberg equilibrium were estimated. These analyses and the test for deviation from Hardy-Weinberg expectations were performed with Genes program (Cruz 2008).

\section{Results and Discussion}

Ten of the 13 microsatellite loci evaluated generated amplification products. In PaA10, PaB12, PaC05, PaD07, PaZ01 and Pit5 loci cross-amplification was successful for the five study species, for the annealing temperature of these primers was identical $\left(54{ }^{\circ} \mathrm{C}\right)$. The other markers had positive results for some of these species (Table 2). In $P$. flammea, there was positive amplification to $10(76.92 \%)$ microsatellites loci, of which only three were monomorphic, in A. Nudicaulis, six (46.15\%) markers generated amplification products, since in five of them polymorphism was detected, to A. ramosa and $B$. horrida, eight (61.53\%) markers were successfully amplified, with only one monomorphic locus and, in B. euphemiae, nine $(69.23 \%)$ markers generated positive results, as in seven polymorphism was detected.

Paggi et al. (2008) used the same markers previously developed for P. albiflos (subfamily Pitcairnioideae) to test cross amplification in 16 other bromeliad species, six of which belong to subfamily Pitcairnioideae, eight to family Bromelioideae and two to family Tillandsioideae. In this paper, $\mathrm{PaB} 12, \mathrm{PaC} 05$ and $\mathrm{PaD} 07$ markers showed positive results of amplification in all species belonging to subfamily Pitcairnioideae. PaA05, PaA09 and PaB11 markers exhibited exclusive transference only to this subfamily. On the other hand, PaA10, PaC05, PaD07 and PaZ01 markers were successfully transferred to species distributed in the three subfamilies. 
Table 1. Characteristics of microsatellite loci used on heterologous amplification tests, including the name of the species for which the marker was previously developed, locus name, primer sequences, microsatellite sequence, size of fragments detected in the original citation and GenBank accession number.

Tabela 1. Características dos loci microssatélites usados nos testes de amplificação heteróloga, incluindo o nome da espécie para a qual o marcador foi originalmente desenvolvido, o nome do locus, a seqüência do primer, a seqüência do microssatélite, o tamanho do fragmento detectado na citação original e o número de acesso no GeneBank.

\begin{tabular}{|c|c|c|c|c|c|}
\hline Species name & Locus & Primer sequences (5'-3') & SSR motif & Size range (bp) & Accession number \\
\hline Pitcairnia albiflos & $\mathrm{PaA} 05^{\mathrm{a}}$ & $\begin{array}{l}\text { F: ACCGGGTTCAGGGAAAATAC } \\
\text { R: TTGAGGCTAAGAGCGAGGAG }\end{array}$ & $(\mathrm{TTC})_{10} \mathrm{NN}(\mathrm{CT})_{17}$ & $228-258$ & EU293085 \\
\hline Pitcairnia albiflos & $\mathrm{PaA09}{ }^{\mathrm{a}}$ & $\begin{array}{l}\text { F: AGAAGAGAACCCACCCCAAG } \\
\text { R: GTGTTCCGCGACACTACAAA }\end{array}$ & $(\mathrm{CT})_{25}$ & $191-213$ & EU293086 \\
\hline Pitcairnia albiflos & $\mathrm{PaA} 10^{\mathrm{a}}$ & $\begin{array}{l}\text { F: AACCATTGACATCCGCTGTT } \\
\text { R: CTTCGGAAGCTCCTCTGGAT }\end{array}$ & $(\mathrm{ATG})_{10}$ & $146-149$ & EU293087 \\
\hline Pitcairnia albiflos & $\mathrm{PaB} 11^{\mathrm{a}}$ & $\begin{array}{l}\text { F: AGAGGCTGAGAGAGGTAAACCA } \\
\text { R: CGAGCCCTCTTTCTGAACC }\end{array}$ & $(\mathrm{AG})_{9}$ & $159-171$ & EU293088 \\
\hline Pitcairnia albiflos & $\mathrm{PaB} 12^{\mathrm{a}}$ & $\begin{array}{l}\text { F: CCCGAGGGACATTCTCTCTT } \\
\text { R: CATGGCGCAGTAGTGTTTTC }\end{array}$ & $\begin{array}{l}(\mathrm{CT})_{19} \mathrm{NN}(\mathrm{CT})_{4} \mathrm{NN}(\mathrm{C} \\
\mathrm{T})_{4} \mathrm{NN}(\mathrm{TG})_{7}(\mathrm{TC})_{5}\end{array}$ & $219-259$ & EU293089 \\
\hline Pitcairnia albiflos & $\mathrm{PaC} 05^{\mathrm{a}}$ & $\begin{array}{l}\text { F: TCGATGTCGACGGTAGTGAG } \\
\text { R: TCCTCTCGCTTTGATTCACC }\end{array}$ & $(\mathrm{AG})_{18} \mathrm{NN}(\mathrm{GA})_{7}$ & $149-153$ & EU293090 \\
\hline Pitcairnia albiflos & $\mathrm{PaD} 07^{\mathrm{a}}$ & $\begin{array}{l}\text { F: TCCATGTGCCTCATCATAGC } \\
\text { R: TGCCCACAAAGCATATCAGT }\end{array}$ & $(\mathrm{TG})_{10}$ & $233-239$ & EU293091 \\
\hline Pitcairnia albiflos & $\mathrm{PaZ01}{ }^{\mathrm{a}}$ & $\begin{array}{l}\text { F: TGACCAGATAGCACCATCCA } \\
\text { R: TTGAGTGTTGGAGCCCACTT }\end{array}$ & $(\mathrm{AG})_{20}$ & $185-199$ & EU293092 \\
\hline Pitcairnia geyskesii & Pit $2^{\mathrm{b}}$ & $\begin{array}{l}\text { L: TTAGCGGCAGTTAGAAACAGG } \\
\text { R: GATCTCCGATGTCTTGTTAGG }\end{array}$ & $(\mathrm{CT})_{13}$ & $191-219$ & AY188957 \\
\hline Pitcairnia geyskesii & Pit $4^{b}$ & $\begin{array}{l}\text { L: CCGACTCTATCGTCAAAGG } \\
\text { R: TTATCACCTCCCATGTCTCC }\end{array}$ & $(\mathrm{CT})_{16}$ & $214-230$ & AY188958 \\
\hline Pitcairnia geyskesii & $\mathrm{Pit5}^{\mathrm{b}}$ & $\begin{array}{l}\text { L: TTGAGCCATGAACAATAGGG } \\
\text { R: AGAATTCTAGTGGCAGTCCTC }\end{array}$ & $(\mathrm{GA})_{20}$ & $310-343$ & AY188959 \\
\hline Pitcairnia geyskesii & Pit6 $^{\mathrm{b}}$ & $\begin{array}{l}\text { L: AAAGCTACATCGTCGAAAACAAC } \\
\text { R: CAATCAAGTTTCGGGTCACTAC }\end{array}$ & $(\mathrm{CT})_{11}$ & $108-120$ & AY188960 \\
\hline Pitcairnia geyskesii & Pit $9^{b}$ & $\begin{array}{l}\text { L: AACCATTACATGCACCCTCAC } \\
\text { R: TCACTGGGGAAGCCATAGAG }\end{array}$ & $(\mathrm{TC})_{13}(\mathrm{AT})_{9}$ & $113-129$ & AY188962 \\
\hline
\end{tabular}

${ }^{a}$ markers described by Paggi et al. (2008) and ${ }^{\mathrm{b}}$ markers described by Sarthou et al. (2003).

In the present study, microsatellite markers, which until then had been described only to species of the genus Pitcairnia, such as PaA05, PaA09 and PaB11, were found to effectively generate cross amplification in species of Aechmea and Billbergia (Table 2), validating the transferability of these markers in these genus. Similar results were found by Palma-Silva et al. (2007) who successfully performed the transposition of SSR markers developed from species of subfamily Tillandsioideae (Vrissea gigantea and Alcantarea imperialis) to Bromelioideae and Pitcairnioideae species.

Another important aspect of our findings was the polymorphic markers identified for each one of the assessed species. Considering only the polymorphic loci, the number of alleles per locus ranged between two and four for most of the species (Table 2). These findings differ from those obtained by Sarthou et al. (2003) and Paggi et al. (2008), regarding the number of alleles detected and the size of fragments generated. According to Wang et al. (2009), this may have occurred because of the different methodologies used, namely capillary electrophoresis in the genotyping studies where these markers were originally described and agarose gel electrophoresis, in the present study. Another possible explanation is that these differences are the result of variations in the number of tandem repeat polymorphisms on the tested loci. In their evaluation of the percentage of transferability of SSR markers developed from Nicotiana tabacum to other species of the same genus, Moon et al. (2008) also found differences in reproducibility of amplifications, with variable fragment sizes, compared to the expected. Bravo et al. (2006) argue that there may be considerably variation both in the number of repetitions as well in levels of polymorphism between the species for which SSR markers were previously developed and the species that showed a cross reaction.

Regarding genotype distribution and values of the expected $\left(\mathrm{H}_{\mathrm{E}}\right)$ and observed $\left(\mathrm{H}_{\mathrm{O}}\right)$ heterozygosity (Table 2$)$, in P. flammea, these ranged between 0.19 (PaA05) and 0.62 (PaZ01), and from zero $(\mathrm{PaA} 05)$ to $0.64(\mathrm{PaC} 05)$ respectively. In A. Nudicaulis, $\mathrm{H}_{\mathrm{E}}$ ranged from 0.33 (PaA10) to $0.64(\mathrm{PaZ} 01)$ and $\mathrm{H}_{\mathrm{O}}$ between 0.25 (Pit5) and 0.63 (PaZ01) (Table 2). In A. ramosa and B. horrida, $\mathrm{H}_{\mathrm{E}}$ ranged from 0.37 (PaA10, Pit5) to $0.63(\mathrm{PaB} 12, \mathrm{PaZ} 01)$ and the values of $\mathrm{H}_{\mathrm{O}}$ were detected ranging between zero $(\mathrm{PaC} 05)$ and 0.77 (PaA05, PaB12) and from 0.25 (Pit5) to 0.77 (PaB12), respectively. To $B$. euphemiae, $\mathrm{H}_{\mathrm{E}}$ ranged from 0.22 (PaA09) to 0.59 (PaZ01) and $\mathrm{H}_{\mathrm{O}}$ ranged between zero (Pit5) and one (PaA05, PaA10, PaC05 and PaD07). Moreover, significant deviations from Hardy-Weinberg equilibrium were observed in some loci in population samples of the five bromeliad species. Similar results were reported by many authors in cross amplification studies using SSR markers for different species (Sarthou et al. 2003, Gimenes et al. 2007, Paggi et al. 2008, Nazareno et al. 2009). In most cases, this can be attributed to the existence of null alleles (alleles not amplified in some genotypes) or to sampling errors, causing the Wahlund effect. Still according to Wright (1965), the level of heterozygosity found in a population is highly dependent on the mating system and on the evolutionary history of the species, as well as on a number of other factors.

Therefore, given the high success rate in the cross amplification test and the level of polymorphism detected, the microsatellite 
Table 2. Results of heterologous amplifications of microsatellite loci in DNA samples of individuals of Pitcairnia flammea, Aechmea nudicaulis, Aechmea ramosa, Billbergia horrida and Billbergia euphemiae species.

Tabela 2. Resultados das amplificações heterólogas de loci microssatélites em amostras de DNA de indivíduos das espécies Pitcairnia flammea, Aechmea nudicaulis, Aechmea ramosa, Billbergia horrida e Billbergia euphemiae.

\begin{tabular}{|c|c|c|c|c|c|c|c|c|c|c|c|c|}
\hline Specie & Loci & PaA05 & PaA09 & PaA10 & PaB11 & PaB12 & $\mathrm{PaC05}$ & PaD07 & PaZ01 & Pit5 & Pit9 & Média \\
\hline \multirow{4}{*}{$\begin{array}{l}\text { P. flammea } \\
(\mathrm{n}=12)\end{array}$} & Size range (bp) & $185-210$ & $215-270$ & 60 & 90 & $240-290$ & $65-85$ & $60-100$ & $250-280$ & 320 & $70-90$ & \\
\hline & $\begin{array}{l}\text { Number of } \\
\text { alleles }\end{array}$ & 2 & 3 & 1 & 1 & 3 & 3 & 2 & 3 & 1 & 2 & \\
\hline & $\mathrm{H}_{\mathrm{O}}$ & 0 & 0.36 & - & - & 0.4 & 0.64 & 0.09 & 0.2 & - & 0.54 & 0.31 \\
\hline & $\mathrm{H}_{\mathrm{E}}$ & $0.19 * *$ & $0.43 *$ & & & 0.46 & 0.53 & $0.23 *$ & $0.62 * *$ & & 0.5 & 0.42 \\
\hline \multirow{4}{*}{$\begin{array}{l}\text { A. nudicaulis } \\
(\mathrm{n}=8)\end{array}$} & Size range (bp) & - & - & $140-160$ & - & 190 & $165-195$ & $250-280$ & $160-200$ & $360-400$ & - & \\
\hline & $\begin{array}{l}\text { Number of } \\
\text { alleles }\end{array}$ & - & - & 2 & - & 1 & 2 & 2 & 4 & 3 & - & \\
\hline & $\mathrm{H}_{\mathrm{O}}$ & - & - & 0.43 & - & - & 0.6 & 0.5 & 0.63 & 0.25 & - & 0.48 \\
\hline & $\mathrm{H}_{\mathrm{E}}$ & & & $0.33^{*}$ & & & 0.62 & $0.37 *$ & 0.64 & $0.55^{* *}$ & & 0.50 \\
\hline \multirow{4}{*}{$\begin{array}{l}\text { A. ramosa } \\
(\mathrm{n}=12)\end{array}$} & Size range (bp) & $380-460$ & - & $130-160$ & $60-110$ & $80-120$ & $85-95$ & $230-260$ & $160-190$ & 380 & - & \\
\hline & $\begin{array}{l}\text { Number of } \\
\text { alleles }\end{array}$ & 2 & - & 2 & 2 & 4 & 2 & 2 & 3 & 1 & - & \\
\hline & $\mathrm{H}_{\mathrm{O}}$ & 0.77 & - & 0.16 & 0.57 & 0.77 & 0 & 0.75 & 0.25 & - & - & 0.47 \\
\hline & $\mathrm{H}_{\mathrm{E}}$ & $0.47 *$ & & 0.37 & $0.41 *$ & $0.63 * *$ & $0.42 * *$ & $0.46^{*}$ & $0.63 *$ & & & 0.48 \\
\hline \multirow{4}{*}{$\begin{array}{l}\text { B. horrida } \\
(n=10)\end{array}$} & Size range (bp) & 280 & - & $130-160$ & $140-160$ & $240-255$ & $250-270$ & $190-210$ & $170-200$ & $345-365$ & - & \\
\hline & $\begin{array}{l}\text { Number of } \\
\text { alleles }\end{array}$ & 1 & - & 2 & 2 & 2 & 2 & 2 & 3 & 2 & - & \\
\hline & $\mathrm{H}_{\mathrm{O}}$ & - & - & 0.55 & 0.57 & 0.77 & 0.44 & 0.63 & 0.66 & 0.25 & - & 0.55 \\
\hline & $\mathrm{H}_{\mathrm{E}}$ & & & $0.5^{*}$ & 0.48 & $0.5^{*}$ & $0.34 * *$ & $0.43 * *$ & $0.62 *$ & $0.37^{*}$ & & 0.46 \\
\hline \multirow{4}{*}{$\begin{array}{l}\text { B. euphemiae } \\
(n=4)\end{array}$} & Size range (bp) & $390-420$ & $140-160$ & $180-210$ & - & 180 & $190-210$ & $230-260$ & $175-195$ & $320-340$ & 380 & \\
\hline & $\begin{array}{l}\text { Number of } \\
\text { alleles }\end{array}$ & 2 & 2 & 2 & - & 1 & 2 & 2 & 3 & 2 & 1 & \\
\hline & $\mathrm{H}_{\mathrm{O}}$ & 1 & 0.25 & 1 & - & - & 1 & 1 & 0.5 & 0 & - & 0.67 \\
\hline & $\mathrm{H}_{\mathrm{E}}$ & $0.5^{*}$ & 0.22 & $0.5^{*}$ & & & $0.5^{*}$ & $0.5^{*}$ & 0.59 & $0.5^{*}$ & & 0.47 \\
\hline
\end{tabular}

The annealing temperature was the same for all the markers $-54{ }^{\circ} \mathrm{C}$; statistically significant deviation from Hardy-Weinberg equilibrium $(* \mathrm{P}<0.005$; $* * \mathrm{P}<0.001)$

markers used here can make a significant contribution to research on genetic structure of natural populations of Bromeliads. As described by Barbará et al. (2007), the findings of the present study provide subsidies to the establishment of effective strategies for conservation of forest genetic resources. Another important aspect is highlighted by Noor \& Feder (2006). According to these authors, the possibility of cross amplification of genetic markers allow comparative studies among closely related taxa, as well as understanding of the genetic mechanisms of speciation and population divergence.

\section{Acknowledgements}

Authors thank biologist Dayvid Rodrigues Couto for his assistance with collection of plant material and Fundação de Amparo à Pesquisa do Espírito Santo (FAPES), for financial support.

\section{References}

BARBARÁ, T., PALMA-SILVA, C., PAGGI, G.M., BERED, F., FAY, M.F. \& LEXER, C. 2007. Cross-species transfer of nuclear microsatellite markers: potential and limitations. Mol. Ecol. 16:3759-3767. http://dx.doi. org/10.1111/j.1365-294X.2007.03439.x
BENZIG, D.H. 2000. Bromeliaceae: profile of an adaptative radiation. Cambridge University, Cambridge. http://dx.doi.org/10.1017/ CBO9780511565175

BONETH, L., KUPERUS, P. \& VAN TIENDEREN, H. 2003. Microsatellites in the bromeliads Tillandsia fasciculata and Guzmania monostachya. Mol Ecol Notes. 3:302-303. http://dx.doi.org/10.1046/j.14718286.2003.00432.x

BRAVO, J.P., HOSHINO, A.A., ANGELICI, C.M.L.C.D., LOPES, C.R. \& GIMENES, M.A. 2006. Transferability and use of microsatellite markers for the genetic analysis of the germoplasm of some Arachis section species of the genus Arachis. Genet. Mol. Biol. 29: 516-524. http://dx.doi. org/10.1590/S1415-47572006000300021

CAVALLARI, M.M., FORZZA, R.C., VEASEY, E.A., ZUCCHI, M.I. \& OLIVEIRA, G.C.X. 2006. pinhaço, Brazil, detected using RAPD markers. Biodivers. Conserv. 15: 4357-4373. http://dx.doi.org/10.1007/ s10531-005-3741-5

CHEN, H.C., SHII, C.T., LIN, S.F., CHIU, H.L. \& CHUNG, J.P. 2002. Genetic relationship between ornamental bromeliads of Centric South America and commercial cultivars in Taiwan. J. Chinese Soc. Hort. Sci. 48:201-210.

CRONQUIST, A. 1988. The evolution and classification of flowering plants. 2nd ed. New York Botanic Garden, New York. 
CRUZ, C.D. 2008. Programa Genes: diversidade genética. Universidade Federal de Viçosa, Viçosa.

DOYLE, J.J. \& DOYLE, J.L. 1990. Isolation of plant DNA from fresh tissue. Focus 12:13-15.

FERREIRA, M.E. \& GRATTAPAGLIA, D. 1998. Introdução ao uso de marcadores moleculares em análise genética. 3rd. ed. CENARGEMEmbrapa, Brasília.

GIMENES, M.A., HOSHINO, A.A., BARBOSA, A.V.G., PALMIERI, D.A. \& LOPES, C.R. 2007. Characterization and transferability of microsatellite markers of the cultivated peanut (Arachis hypogaea). BMC Plant. Biol. 7:1-13. http://dx.doi.org/10.1186/1471-2229-7-9

KATZIR, N., DANIN-POLEG, Y., TZURI, G., KARCHI, Z., LAVI, U. \& CREGAN, P.B. 1996. Length polymorphism and homologies of microsatellites in several Cucurbitaceae species. Theor. Appl. Genet. 93:1282-1290. http://dx.doi.org/10.1007/BF00223461

KÖLLIKER, R., JONES, E.S., DRAYTON, M.C., DUPAL, M.P. \& FORSTER, J.W. 2001. Development and characterization of simple sequence repeat (SSR) markers for white clover (Trifolium repens L.). Theor. Appl. Genet. 102:416-424. http://dx.doi.org/10.1007/s001220051662

LITT, M. \& LUTY, J.A. 1989. A hypervariable microsatéllite revealed by in vitro amplification of a dinucleotide repeat within the cardiac muscle actin gene. Am. J. Hum. Genet. 44:397-401.

LUTHER, H.E. 2008. An Alphabetical List of Bromeliad Binomials. 11th ed. Bromeliad Society International, Florida.

MOON, H.S., NICHOLSON, J.S. \& LEWIS, R.S. 2008. Use of transferable Nicotiana tabacum L. microsatellite markers for investigating genetic diversity in the genus Nicotiana. Genome 51:547-559. http://dx.doi. org/10.1139/G08-039

NAGY, I., STÁGEL, A., SASVÁRI, Z., RÖDER, M. \& GANAL, M. 2007. Development, characterization, and transferability to other Solanaceae of microsatellite markers in pepper (Capsicum annuum L.). Genome 50:668688. http://dx.doi.org/10.1139/G07-047

NAZARENO, A.G., PEREIRA, R.A.S., FERES, J.M., MESTRINER, M.A. \& ALZATE-MARIN, A.L. 2009. Transferability and characterization of microsatellite markers in two Neotropical Ficus species. Genet. Mol. Biol. 32:568-571. http://dx.doi.org/10.1590/S1415-47572009005000056

NOOR, M.A.F. \& FEDER, J.L. 2006. Speciation genetics: evolving approaches. Nature Rev. Genet. 7:851-861. http://dx.doi.org/10.1038/ $\operatorname{nrg} 1968$

PAGGI, G.M., PALMA-SILVA, C., BERED, F., CIDADE, F.W., SOUSA, A.C.B., SOUZA, A.P., WENDT, T. \& LEXER, C. 2008. Isolation and characterization of microsatellite loci in Pitcairnia albiflos (Bromeliaceae), an endemic bromeliad from the Atlantic Rainforest, and cross-amplification in other species. Mol. Ecol. Resour. 8:980-982. http:// dx.doi.org/10.1111/j.1755-0998.2008.02126.x

PALMA-SILVA, C., CAVALLARI, M.M., BARBARÁ, T., LEXER, C., GIMENES, M.A., BERED, F. \& BODANESE-ZANETTINI, M.H. 2007. A set of polymorphic microsatellite loci for Vriesea gigantea and Alcantarea imperialis (Bromeliaceae) and cross-amplification in other bromeliad species. Mol. Ecol. Notes 7:654-657. http://dx.doi.org/10.1111/ j.1471-8286.2006.01665.x
PEAKALL, R., GILMORE, S., KEYS, W., MORGANTE, M. \& RAFALSKI, A. 1998. Cross-species amplification of soybean (Glycine max) simple sequence repeats (SSRs) within the genus and other legume genera: implications for the transferability of SSRs in plants. Mol. Biol. Evol. 15:1275-1287. http://dx.doi.org/10.1093/oxfordjournals.molbev. a025856

PIZO, M.A. 1994. O uso das bromélias por aves da mata atlântica da Fazenda Intervales, sudeste do Brasil. Bromélia 1(4):3-7.

POWELL, W., MACHRAY, G.C. \& PROVAN, J. 1996. Polymorphism revealed by simple sequence repeats. Trends Plant. Sci. 1:215-222.

PROVAN, J., POWELL, W. \& WAUGH, W. 1996. Microsatellite analysis of relationships within cultivated tomato (Solanum tuberosum). Theor. Appl. Genet. 92:1078-1084. http://dx.doi.org/10.1007/BF00224052

RÖDER, M.S., PLASCHKE, J., KÖNING, S.U., BÖRNER, A., SORRELLS, M.E., TANKSLEY, S.D. \& GANAL, M.W. 1995. Abundance, variability and chromosomal location of microsatellites in wheat. Mol. Genet. Genom. 246:327-333. http://dx.doi.org/10.1007/BF00288605

SAGHAI MAROOF, M.A., BIYASHEV, R.M., YANG, G.P., ZHANG, Q. \& ALLARD, R.W. 1994. Extraordinarly polymorphic microsatellite DNA in barley - species diversity, chromosomal locations and population dynamics. Proc. Natl. Acad. Sci. USA 91:5466-5470. http://dx.doi. org/10.1073/pnas.91.12.5466

SARTHOU, C., BOISSELIER-DUBAYLE, M.C., LAMBOURDIERE, J. \& SAMADI, S. 2003. Polymorphic microsatellites for the study of fragmented populations of Pitcairnia geyskesii L. B. a specific saxicolous species of inselbergs in French Guiana. Mol. Ecol. Notes 3:221-223. http://dx.doi.org/10.1046/j.1471-8286.2003.00404.x

SIQUEIRA FILHO, J.A. \& LEME, E.M.C. 2000. Suplemento: Neoregelia Subgênero Longipetalopsis. In Nidularium: Bromélias da Mata Atlântica (E.M.C. Leme, ed.). Sextante Artes, Rio de Janeiro, p.229-237.

SMULDERS, M.J.M., BREDEMEIJER, G., RUS-KORTEKAAS, W., ARENS, P. \& VOSMAN, B. 1997. Use of short microsatellite from database sequences to generate polymorphisms among Lycopersicon esculentum cultivars and accessions of other Lycopersicon species. Theor. Appl. Genet. 94:264-272. http://dx.doi.org/10.1007/s001220050409

THIEL, T., MICHALEK, W., VARSHNEY, R.K. \& GRANER, A. 2003. Exploiting EST databases for the development and characterization of gene-derived SSR-markers in barley (Hordeum vulgare L.). Theor. Appl. Genet. 106:411-422.

WANG, X., RINEHART, T.A., WADL, P.A., SPIERS, J.M., HADZIABDIC, D., WINDHAM, M.T. \& TRIGIANO, R.N. 2009. A new electrophoresis technique to separate microsatellite alleles. Afr. J. Biotechnol. 8:2432-2436.

WRIGHT, S. 1965. The interpretation of population structure by F-statistics with special regard to system of mating. Evolution 19:395-42. http:// dx.doi.org/10.2307/2406450

YAMAMOTO, T., KIMURA, T., SAWAMURA, Y., MANABE, T., KOTOBUKI, K., HAYASHI, T., BAN, Y. \& MATSUTA, N. 2002. Simple sequence repeat for genetic analysis in pear. Euphytica 124:129-137. http://dx.doi.org/10.1023/A:1015677505602

YU, F., WANG. B.H., FENG, S.P., WANG, J.Y., LI, W.G. \& WU, Y.T. 2011. Development, characterization, and cross-species/genera transferability of SSR markers for rubber tree (Hevea brasiliensis). Plant Cell. Rep. 30:335-344. http://dx.doi.org/10.1007/s00299-010-0908-7 